\title{
Quest for College English Classroom Teaching Mode under Multimedia and Network Environments
}

\author{
Sheng-Hua $\mathrm{CAO}^{1, \mathrm{a}}$ \\ ${ }^{1}$ School of Foreign Studies, North China University of Water Resources and Electric \\ Power, Zhengzhou 450046, China \\ ashenghuacao@126.com
}

Key words: Multimedia and network environments, College English, Classroom teaching mode.

\begin{abstract}
With the rapid development of science and technology, modern information technology and Internet represented by computers have been widely used in every field of education. Information technology has become an indispensable part of college English classroom. College English classroom teaching under the environments of Network will break the limitation of the traditional classroom teaching mode, organically combine text, graphics, video, animation and sound technology together, expand the capacity of classroom teaching, and increase the vividness, intuition, and vitality of the classroom teaching. All these will greatly promote the interaction between teachers and students, and enhance the classroom efficiency greatly.
\end{abstract}

\section{Introduction}

With the rapid development of information technology, modern information technology and Internet represented by computers have been widely used in every field of education. In 2004 the ministry of education promulgated "college English curriculum requirements (trial)" explicitly pointed out: "Every institutions of higher learning should make full use of modern information technology, adopt English teaching mode based on computer and the classroom to improve the mainly teacher-oriented, single teaching mode. The new teaching pattern should take the modern information technology, especially network technology as the support, in order to make the English teaching and learning move forward in the direction of individualization and autonomous learning, to a certain extent, without the limitation of time and place, ".[1] At present, more and more colleges and universities across the country have taken the reform and practice of college English teaching based on computer and the Internet, and have achieved gratifying results.

\section{The disadvantages of traditional college English classroom teaching mode}

Classroom teaching is an important link in the process of college English teaching. The traditional college English classroom teaching still has some disadvantages due to the limits of various conditions, and the effect is not ideal.

\section{Traditional college English teaching is lack of humanistic teaching philosophy.}

In traditional classroom teaching, teachers are the center of the classroom teaching, they transmit the knowledge with only mouth, a piece of chalk. The students listen and accept passively, rote learning, and have less opportunities to participate in teaching activities, students' learning initiative and enthusiasm cannot fully play and display, which leads to losing interest and driving force in learning English for most of the students. Single traditional model of "text + chalk + blackboard" had caused students' visual fatigue, made the atmosphere of classroom dull, little chance for communication and interaction between teachers and students, resulted in lower efficiency of college English teaching and a huge waste of education resources.[2]

\section{Traditional classroom teaching contents are quite limited}

As for the traditional college English classroom, the amount of teaching information, teaching contents are quite narrow. With blackboard, chalk, recorder and other simple teaching equipment, teachers can hardly present a large amount of information to the students effectively in class, thus 
reducing the number of targeted topics of discussion. In addition to the common phenomenon of limited teaching hour and little available teaching equipment, the limited time of classroom teaching and backward teaching method greatly inhibited the efficiency of the classroom teaching.

\section{The advantages of multi-media and network auxiliary English teaching mode}

Years of teaching practice shows that the traditional mode of college English classroom teaching is stylized and lack of energy, which cannot meet the needs of cultivating social needed talents with English practical ability effectively. Therefore, the change of teaching thought and the reform of teaching model are imminent and necessary. Multi-media and network teaching, which is based on constructivism learning theory and make full use of modern information technology, is an advanced teaching mode, it will create a kind of brand-new teaching situation for the students. This teaching mode embodies the English teaching principle of combining practice, knowledge and interests together, which is helpful to arouse the enthusiasm of both teachers and the students, and particularly shows the dominant position of the students and the leading role of the teachers in the process of teaching; it has a wide range of advantages.

\section{Extending the contents of classroom teaching, enriching the learning resources, and expanding the capacity of knowledge}

Under the multimedia environment, the teachers have prepared their teaching courseware well in advance, they demonstrate them while teaching, through the projection on a screen, which not only saves time, but also makes the teachers get rid of the limitation of the blackboard, the application of multimedia makes the teaching blackboard writing capacity doubled. This teaching mode with multimedia CD-ROM, projectors, courseware, makes students learn more than the traditional teaching method within the same unit of time. Information has a significant increase in the amount of classroom teaching. Teachers can take the advantages of multimedia computers' large information storage and its concise and convenient characteristic to strengthen the density of teaching knowledge, speed up the pace of teaching.[3] Through the use of multimedia, teachers can show the students more vivid contents and offer them more opportunities to participate in classroom activities, thus increasing the density of the teaching content. The transformation of text explanation, practice, group-discussion, question and answer in the process of College English teaching, making alternating rhythm more compact and smooth, and greatly improved the quality and teaching efficiency.

\section{Optimizing the teaching environments, having improved teaching performance}

Multimedia combines text, graphics, video, voice and other media together and applies it to the process of teaching skillfully, which can provide students with a vivid and interesting teaching environment with colorful pictures and illustration. Through various forms of expression, the teacher can greatly enhance the teaching force. Some abstract and difficult concept to understand can be intuitively reappeared, some boring pattern practice can be designed in a simulated scenario to make students easily understand, the display of cultural background knowledge can be demonstrated not only by text, but also can be equipped with related images or video materials. This is easy to make teaching important points, difficult points stand out, and impressed the students deeply. Rich and colorful multimedia and multi-channel ways of teaching make English teaching more rich and colorful.

\section{Creating good teaching atmosphere, being beneficial to classroom teaching}

With the aid of network and multimedia, teachers can adjust the atmosphere of classroom teaching through the use of images, animation, film clips, and other forms of music, and create a light, relaxed classroom atmosphere with pleasant, moderate tension, which is very helpful for students to get rid of the bad feelings, such as anxiety and stress suffered by the traditional, simple, 
and boring teaching mode, in which students can focus their attention entirely on the learned knowledge, making teaching smoothly and achieving good teaching effect.

\section{Improving students' interests in learning, arousing the initiative of students}

Psychology research shows that interest is the power for people to explore the things in the world. Therefore, the success of English teaching, to a large extent depends on the students' interest in English. So the educator must constantly strive to make the teaching content novel and fascinating. Multi-media provide a potential technology support for the teacher to design variety forms of classroom teaching. Multimedia and network aided teaching has changed the traditional pattern of English classroom teaching, students have no longer to face the boring textbooks and stereotyped teachers, but the intuitive and authentic language materials, learning becomes vivid and concrete, full of appeal. The multimedia technology used in classroom teaching can create an vivid, interesting and authentic English language environment for students to image. Combined with the use of the network, it can make the language more fashionable and contagious, greatly reduce the distance between teachers and students, and the relationship between the teachers teaching and the students learning are becoming more and more harmonious, which stimulated the students' strong interest in English study, aroused the enthusiasm of the students' classroom participation, achieved the effect of classroom interaction, and finally completely overcome the passive situation of the students in the traditional classroom teaching .

\section{Complying with the rules of foreign language learning, being benefit to improving the learning efficiency}

In 1967, psychologist Treicheer made a conclusion after a long period of study that $11 \%$ people's learning is through the hearing, 83. 5\% is by the sense of vision. (SHI Shu-en,1993). [4] That is to say, about $94 \%$ information people got is achieved through the sense of hearing and vision. And multimedia in English teaching can simultaneously stimulate the students' auditory and visual organs up to the hilt, making graphics and sound affect students' various senses at the same time, causing both the right and the left sides of brain thinking positively. The final purpose of English teaching is to cultivate students' practical ability to use English, such as English listening, speaking, reading, writing and translating ability. Multimedia and network assisted classroom teaching created an approximate real language environment for the students to learn English by simulating real language scene, so that they can acquire language naturally, which conforms to the law of language acquisition.

\section{Network and the multimedia auxiliary English teaching helping to develop students' cognitive space, being benefit to improving students' comprehensive quality}

Using computer's storage and call functions, teachers can flexibly display all sorts of relevant information which is good for students in the classroom, helping students to develop the knowledge out of their textbooks or the forefront information of their study field, expanding the horizons of students, promoting effect on improving students' comprehensive quality, and fully adapting to the talent requirements in new era. Teachers can collect a wide range of information through modern network technology, expand the breadth and depth of language teaching through the multimedia display, and penetrate relevant cultural background knowledge in language teaching, so that to improve the students' cross-cultural communication ability subtly in the process of learning foreign culture.

\section{Network and multimedia auxiliary teaching mode should pay more attention to the following points}

The college English course requirements pointed out: "regardless of courses which mainly based on the computer, or the course mainly based on the classroom teaching, the courses setting should be fully embodies individuation, considering the students with different starting points, which not only take care of the students with the lower starting point, but also leave the development space for 
the students with the good basic knowledge, thus can not only help students lay a solid language foundation, but also can cultivate their stronger actual application ability, especially the listening and speaking skills, in order to guarantee to improve the students language level steadily throughout the whole college English learning, and help students to learn and satisfy his or her own professional development". [1]Although the network and multimedia technology has brought great help to the college English teaching, but like any other teaching methods, it is not absolutely perfect. We also should pay more attention to the following questions while teaching.

1. English teachers should clearly realize that the purpose of using multimedia and network in classroom teaching is just to assist teaching. College English teaching is ultimately the language teaching, its basic goal is to cultivate students' language communicative competence. Multimedia is a kind of auxiliary means, which is used to show the teaching thought, teaching content much better, to stimulate students interest in learning, make the teaching go smoothly. [5] So college English teachers should avoid making college English class into a multimedia courseware projected class while using the multimedia as an auxiliary teaching method, and the teachers become the mechanical projectionists.

2. Avoiding paying too much attention to multimedia and ignoring the conventional teaching methods in the process of teaching. Traditional teaching method has its own advantages. Sometimes, it can't be replaced by modern multimedia teaching mode. One of the purposes of teaching model reform is to promote the formation of students' individualized learning methods and the development of students' autonomous learning ability. New teaching model should be able to make students choose the learning material and learning method according to their own need, acquire the guidance of the learning strategy by themselves, and gradually improve their autonomous learning ability. So only by using multimedia and network rationally in the classroom, combining the modern media and traditional teaching method together, can we make good use of them and expend their own strengths, and maximize the classroom teaching efficiency.

3. While making full use of multimedia auxiliary teaching, we should still adhere to the leading role of teachers. Teacher is the soul of the classroom teaching, the courseware designed must conform to the teachers' teaching ideas and teaching style, otherwise the classroom teaching will become mechanical multimedia display, which will lose his own life. Teachers have a coherent and sustained influence on their students, whose personality directly influence on their teaching. Rich emotional interaction between teachers and students in class is the most effective way of teaching, which can't be replaced by machines. Teacher's leading roles in classroom are irreplaceable and valuable. So keep in mind the teacher's dominant position when applying multimedia in the classroom.

4. Avoiding too large amount of information and too fast rhythm in multimedia and network auxiliary classroom teaching. Some teachers are blindly in the pursuit of information, and want to list all the material and content related to the text, students are surrounded by dazzling and enormous information and almost have no time to think, to digest, and even to take a note. They could not absorb and accept the information purposely, which will greatly reduce the teaching effect and not worth the candle in the end. Teachers must carefully select the teaching content and material, which are helpful to deepen students understanding, instead of driving students drown in the sea of information. They should elaborately select and process the given material and make them more logic and clear, and easily to understand. [6] Finally, pay attention to leaving a space for students to think. Multimedia and network auxiliary classroom teaching is a new teaching method, it can integrate the existing teaching resources, and play a very important role in ensuring the quality of college English teaching. It can solve many problems which the traditional classroom teaching is unable to avoid, and make up the inadequacy of conventional teaching methods. However, any kind of teaching method has its own advantages, it is not perfect. The traditional pattern of classroom teaching still has an irreplaceable part. So both should be combined organically, in order to foster strengths and circumvent weaknesses, to optimize the integration of modern technology and traditional teaching mode. 


\section{Summary}

The reform of teaching mode is a systematic project, it does not mean the change of teaching methods and teaching means, but also the change of teaching concept, it is the practice of teaching thought, it is the change from simple teacher-centered teaching of language knowledge and skills to student-centered teaching, both language knowledge and skills are transmitted, paying more attention to cultivating the language application ability and autonomous learning ability of the students, the purpose is to cultivate the students' lifelong learning ability and make them realize the importance of life-long education. Network and the multimedia auxiliary teaching are still in the stage of practice, how to properly use the modern technology in teaching remains to be further research.

\section{Acknowledgement}

This research was financially supported by the National College Foreign Language Teaching Foundation of China (Grant NO. Yu-0024-A) and was one of the National College Foreign Language Teaching Research Projects.

\section{References}

[1] Higher Education Department, the Ministry of Education. College English Curriculum Requirements [S]. Shanghai: Shanghai foreign language education press, 2007.

[2] Zhang Hongling. The development trend of modern foreign language teaching and machine auxiliary language teaching [J]. Foreign language audio-visual education, 2000 (9).

[3] Cha Guorong, etc. The idea of computer auxiliary college English teaching [J]. Journal of shandong foreign language teaching, 1999 (1).

[4] Shi Shuen. Computer aided education [M]. Beijing: Beijing normal university press, 1993., P192-196.

[5] Hu Wenzhong. The teaching and learning of English [M]. Beijing: Foreign language education and research press, 1989. P76-79.

[6] He Gaoda. The theory and application of multimedia auxiliary teaching research [M]. Taibei: Wanren publishing house, 2001. 